\title{
The Impact of Capital Market on Nigeria's Economic Development (1989-2006)
}

\author{
Jamala, G. $\mathrm{Y}^{1^{*}}$, Abubakar $\mathrm{A}^{2}$., Asongo, $\mathrm{A}^{3}$ and Joel, $\mathrm{L}^{1}$ \\ ${ }^{1}$ Adamawa State College of Agriculture, Ganye, Nigeria \\ ${ }^{2}$ American University of Nigeria, Yola \\ ${ }^{3}$ Modibbo Adama University of Technology, Yola, Nigeria
}

\begin{abstract}
This study was conducted to examine the impact of capital market on Nigeria's economic development and also to analyse the roles of capital market variables on Nigerian economic development. The methodology adopted involved the use of regression analysis. The data obtained was from 1989 to 2006. The sources of data obtained were from Nigerian Stock Exchange (NSE) and Central Bank of Nigeria (CBN) Statistical Bulletin, 2006. One model was used and specified, that is the real gross domestic product (RGDP) as the dependent variable and the explanatory variables $\left(b_{0}, b_{1}, b_{2}, b_{3}, b_{4}\right)$ which includes value of transactions (VOT), All share index (ASI), Foreign Private Investment (FPINM) and Market Capitalization (MCAP). The ${ }^{2}$ for the estimate was 0.97 and it was the highest the adjusted $R=0.96$. This implies that about $97 \%$ variation in the real gross domestic product output is explained by the explanatory variables. That is, there was positive relationship between the dependent and independent variables. In order to test the hypothesis stated, the t-value and 2 tailed p-values were used. $H_{0}$ : This stated that there was no significant impact of capital market on Nigeria's economic development. That is the coefficient or parameter is zero (0) was rejected since the p-value $(0.000)$ when compared to the alpha level $(P<0.05)$ is small. This shows that the capital market has significant impact on Nigeria's economic development and hence the $H_{0}$ is rejected and $H_{I}$ is thus accepted and conclude that the capital market has a significant impact on the Nigeria's economic development.
\end{abstract}

Key words: Economic development, Capital market, Gross domestic product, Impact

\section{Introduction}

The Nigeria Capital market is a long term financial market and the most credible and efficient source of long term funds. It is made up of market and institutions which facilitate the issuance of secondary trading of long term financial instruments. Afolabi (1999) established that an economy requires resources for its development. In view of that, the capital market provides funds to industries and government to meet their long term requirements such as financing for fixed investment, building, plants, bridges. Iwegbu (2004) also maintained that it is the section of the financial system that provides medium to long term funds for the investment needs of business and government.

The capital market is the segment of the financial system through which long term funds are mobilized and channelled for productive investment. It also proved to be a means of trading existing securities and encourages large scale enterprise to gain access for public listing. Therefore, the respective expectation of what the capital market should do; what part it actually plays in the economy, and how efficient it has fulfilled these roles. Will be examined the operations of the capital market and asses the impacts it exerts on the overall economic development of Nigeria. According to Afolabi (1999) 'most Nigerians even those well versed in the other fields of endeavours know little about the capital market operation". The research therefore intends to unveil the activities and operations of the capital market and asses the importance of investing in long term assets so as to encourage the populace to invest in the market for the overall economic development of the country.

Capital market has always been perceived as the engine of the economic development, because it performs a resources allocation function by mobilizing and channelling resources from saving surplus economic units to saving deficit units for productive investment. The market also helps in stimulating the level of economic activities in various sectors of the economy. The low participation of investors can be accounted as lack of public awareness on the process and importance of investing in a long term securities and the misinterpretation of the capital market activities. In view of the above, the researchers intend to take a deep look into the activities and operations of the capital market. This is to broaden the understanding of potential investors on the procedures and importance of investing in capital market.

\section{Research hypotheses}

Ho: There is no significant impact of capital market on Nigerian's economic development.

H1: There is a significant impact of capital market on Nigerian economic development. 


\section{Introduction to capital market}

From the perspective of economic development, a well developed capital market is essential in that it will provide opportunity for mobilizing funds for long term investment, in an efficient financial market. The funds mobilized are for effective development of the economy, which is what an economy requires for its development according to Afolabi (1999). The aim of the capital market is to facilitate the exchange of securities between buyers and sellers, to reducing the risk of speculation (Onwuliri, 2008).

According to Rose (1997); trading of funds in the capital market makes possible the construction of factories, highways, and schools. Financial instrument in the market have maturity dates of more than one year. The principal suppliers of funds in the market are individuals, banks, corporate organization, and the insurance companies, while the principal demanders of funds are companies, government and individuals. In Nigeria, the net foreign Direct Investment was \$588 million USD in 1990 and \$897 million USD in 1992, then to \$1.96 billion USD in 1995 and \$1.53 billion USD in 1997.

In continuance of the evolution of policy towards increased market orientation which reached its peak during the various trade policies of the 1990's Foreign Exchange (Monitoring and Miscellaneous) provision Decree of 1995 and host of other policies that were promulgate to enhance the growth of the manufacturing sector, and in series of major policy reform affecting primarily the banking, capital market, trade and tax, had a significant impact on the performance of the manufacturing sector $(\mathrm{CBN}, 2003)$.

According to Jerome and Adenikinju (1995), export-led growths have a stimulating influence across the whole economy in the form of technological spill over and other externalities. This denotes that exposure to international market increase efficiency, provides incentives for product and process innovation, increase stock of knowledge and human capital and generates overriding benefits to the economy as a whole.

The major's participants in the capital market are;

1. The central bank of Nigerian (CBN)

2. The Nigerian stock exchange (NSE), a self regulatory organization in the capital market that supervises the operations of the formal quoted stock.

3. The Securities and Exchange Commission (SEC) which is responsible for the overall regulations of the entire market.

4. The Federal Ministry of Finance.

Odife (1999), define capital market as a network of institution that performs function that is described as capital market activities. According to him, the market is a framework of institutions that arrange for long term financial asset such as, debentures stock, and mortgages.

Chijoke (2002): also define capital market as a place where the demand for long term funds is met. He also says that the market provide opportunities for companies to acquire some permanent investment funds. Based on the definitions of capital market above, it can be seen that, it is an arrangement through which companies and government raise long term investment which foster economic development.

The stock exchange which is the focus of the study is defined by Afolabi (1999); as a market for buying and selling stock, shares and securities. On the other hand, Chijoke (2002) define the stock exchange as the market place where accredited dealing members buy and sell existing stocks and shares for their clients.

\section{Accessing the Nigerian capital market}

When a company or government wants to use the capital market raise long term funds. It must consult an issuing house or stock brokers. These specialists provide the company or government with financial advisory services. It is there duty to study the company's performance over the years in order to determine its financial needs. More so, they do not only advise on the best option, they undertake total financial restructuring of the company before introducing the facility to the company (Dada 2003)

The issuing house and the stock broker liaise with the other parties-Registrars, Trustees, Auditors, Reporting accountants and Solicitors, to produce a marketing document known as PROSPECT. The prospect is the document the public relies on for marketing investment decision. Necessary approval from the Securities and Exchange Commission (SEC) and other bodies are obtained. If the financial option involves listing on the stock exchange, the broker to the issuer ensures that all necessary approval with the exchange are also obtained since only stockbrokers can introduce issues to the exchange. On the company for executing the proposed business program on long term investment and the securities is listed on the daily official list of the stock exchange (Dada 2003)

For individuals wishing to invest in the stock market in form of buying shares, what they need to do is to consult a stock broking firm and register with the broking firms. Stock broking firm are member firm of the stock exchange which provides share trading services to the public and also on deals on its on account (Dada 2003) 
The Nigeria stock exchange (NSE) is the centre point of the Nigeria capital market. While the Securities and Exchange Commission (SEC) serves as the apex regulatory body of Nigerian capital market (Onwuliri 2008).

\section{Performance of the stock exchange market (2003-2004)}

Real economic development in 2003 is weak. This was due mainly to partial implementation of policy proposal during the year, the protected crises in Niger-Delta, which constrained government revenue in spite of the stability in the international oil market and raising government expenditure that was not matched by revenue (Oladeji 2004). Inflation remained high as a result of the deregulation of petroleum product prices, exchange rate depreciation and raising energy costs.

The manufacturing sector contended with low capacity utilization in the week of increased cost of production, low demand, high demand, for import and epileptic infrastructural services. During the, federal government demonstrated its commitment to proper management of the nation's dept, as it returned to the capital market with a N150 billion bond issue. The proceeds of the bond issued would in part be applied to the reduction of the domestic debt overhang, but beyond dept management. This initiation has worked to deepen the capital market and broaden the spectrum of available finance instrument in the economy. Also the ban on importation of certain commodities during the year engendered fresh investment in the industrial sector, boosting local job creation among other economic benefits (Oladeji 2004)

\section{Market Turnover (2003)}

Turnover on the Nigerian stock exchange in 2003 stood at N120.7 billion up by $100.17 \%$ on the N59accounted in 2002. The bulk of these transactions were in the equities sector of the market which accounted for $99.2 \%$ (N59.3 billion) of the turnover value. All through the year, the industrial loans/ preference stock sector of the market remained inactive, meagter transaction were recorded in the Federal government development stock sector and the state government bonds sector. A turnover of N2.3 millisn in 6 deals and a turnover of 1.5 million shares worth N775million in 5 deals respectively were trade (Oladeji, 2003)

\section{Trading In Rights}

A total of N55.5 million rights, were exchanged in 276 daels valued at N64.5 million, in value terms this represent $227.4 \%$ increase over the turnover recorded in 2002 (Oladeji 2004)

\section{New Issues}

Government and companies had to affirm fate in the stock market in 2003. During the year, the exchange considers and approved 26 applications for new issues valued at N185.0 billion.

During the review period, new issues applicants raised N5.03 billion through initial public offer of share, N15.17 billion through rights issue N157.6 billion through bonds and N650.0 million through debentures. Listings by introduction accounted for N1.3 billion of the issues and approved by the exchange during the year. (Oladeji 2004)

\section{Market Capitalisation}

The total market value of 265 securities listed on the Exchange appreciated by $77.90 \%$ to end the year at N1.359 trillion. On $19^{\text {th }}$ November, the market capitalization attained an all time high of N1.368 trillion. The market capitalization attained and exceeded the one trillion naira mark on $25^{\text {th }}$ September 2003. The Exchange admitted for listing the N15 billion second Lagos State Revenue bond. (Oladeji 2004)

\section{Market Development}

In 2003, the exchange commenced workers on the proposed upgrade of the trading, clearing and settlement system which will be conducted in the year 2004 and restructured and re-engineered its business process for enhanced efficiency. This when fully concluded and lunched will enable members to deal on the exchange from remote locations, taking advantage of the internet technology. With the commissioning of the ebusiness platform in July 2002, it is now possible for investors on the exchange market to access their central securities clearing system (CSCS) database from the exchange website for the purpose of monitoring movement in their stock accounts. As part of the on going effort to take market closer to Nigerians, Adamawa State Yola branch was successfully opened on $13^{\text {th }}$ April 2002 (Onwukiri 2008).

\section{All-Share Index}

The Nigerian stock exchange All-share index grew by $65.84 \%$ to close the year at $20,128,94$. On $19^{\text {th }}$ November, the index had attained an all time high of 21,147.24 before dropping to its year end position. The performance of the index attests to the resilience of our quoted companies (Oladeji 2004) 


\section{The functions of the Nigerian Capital Market}

The services provided by the Nigerian capital market include the following;

1. Provision off an additional channel for engaging and mobilizing domestic saving for productive investment and represent an alternative to bank deposits, real estate investment and financing of consumption loans.

2. Provision of depositors with better protection against inflation and currency depreciation.

3. Improving the gearing of the domestic corporation sector and helps reduce dependence on borrowing.

4. Facilitating the transfer of enterprise from the public sector to the private sector.

5. Encouraging privatization by increasing the marketability of new issues.

6. Providing access to finance for new and smaller companies and encourage institutional development in facilitating the setting up of Nigerians domestic funds. (CBN 2007)

\section{How Capital Market Stimulates Economic Development}

The importance of the capital market is that it facilitates the raising of medium to long term funds for acquisition of fixed assets and implementation of long term project, The capital market stimulate economic development through the following;

1. Mobilizing idle funds from surplus unit in the economy to deficit units, where these resources are utilized to generate goods and services and employment for the economy.

2. Access to finance to companies either for expansion or modernizations. It is a source of finance to Local, State and federal governments for development project at relatively cheaper rate than can be obtained from other sources.

3. Provides liquidity for investment funds and also serve as a measure of confidences in the economy and as an important economic barometer. Though the price mechanism, the market provides management of quoted companies' important information about the performance and public perception of their companies.

4. Provides a reliable medium for broadening the ownership of private companies and for enlarging the shareholding structure of already quoted companies.

5. A veritable source of attracting foreign investment. The Nigerian stock exchange has continued to record an impressive performance in foreign investment transaction. (CBN, 2007)

\section{Study Area}

\section{Materials and Methods}

Nigeria is situated between $3^{\circ}$ and $14^{\circ}$ East Longitudes and $4^{\circ}$ and $14^{\circ}$ North Latitudes. The rainfall ranges between $3500 \mathrm{~mm}$ in the coastal area and $500 \mathrm{~mm}$ in the northern most part of the country. Nigeria has three broad and distinct ecological zones namely the Rain forest, Guinea Savanna and Sudano-Sahelian. Politically, the country is made up of 36 states and Abuja the Federal Capital Territory (FCT).

According to World Bank, the Nigerian Stock Exchange is the largest in African and it ranked $37^{\text {th }}$ in the world in terms of GDP as in 2007. Nigeria is the major country trading with United States of American in the sub Saharan Africa which supplies fifth of its oil and only $11 \%$ as imports. At present is $50^{\text {th }}$ largest export for U.S goods and $14^{\text {th }}$ largest exporter of goods to the U.S. Nigerian Economy is the largest in West Africa and second largest in African following the South Africa. (Wikipedia)

\section{Sources of data}

Data for this study was collected mainly from the Secondary source. The source includes among others, published variable such as bulletin annual report from Securities and Exchange Commission (SEC), Central Bank of Nigeria (CBN), Nigerian Stock Exchange (NSE) and Federal Ministry of Finance (FMF).

\section{Data collection}

The data for the study was collected over a period of eighteen years (1989-2006). In an attempt to investigate the impact of Nigerian capital market operation on economic development, data was collected on real GDP which was served as proxy for economic development. Other data to be collected will include those on market capitalization, All shares Index, values of transaction and Foreign Private Investment.

\section{Method of Data Analysis}

The techniques used for data analysis include; econometric technique, Ordinary least Square (OLS). Data obtained were subjected to regression analysis with the aid of Statistical Package for the Social Science (SPSS, Version 15) was performed

\section{Model Specification}


The first step in this research work was to set the expression of the relationship in the mathematical form. In other word its entails specifying the model which the economic phenomenon will be explained empirically.

\section{Variables of the Model}

The variables of the models are divided into two major components.

$\mathrm{RGDP}=\mathrm{F}$ (VOT, FTPINM, ASI, and MCSP)...

$\mathrm{RGDP}=\mathrm{B}_{0}+\mathrm{B}_{1} \mathrm{VOT}+\mathrm{B}_{2} \mathrm{FPINM}+\mathrm{B}_{3} \mathrm{ASI}+\mathrm{B}_{4} \mathrm{MCAP}+\mathrm{U}$

Where;

RGDP $=$ Real Gross Domestic Product

VOT $=$ Values of Transaction

FPINM= Foreign Private Investment

$\mathrm{ASI}=$ All share Index

MCAP $=$ Market Capitalization

$\mathrm{B}_{0}, \mathrm{~B}_{1}-\mathrm{B}_{4}=$ Coefficients of the variables

$\mathrm{u}=$ constant Error term

\section{Data input (Requirement)}

The data requirement would be the major indicators of RGDP, VOT, FPINM, ASI, and MCAP from (1989-2006) of the performance of capital market in Nigeria.

\section{Results and Discussion}

The data entered into the model for analysis shows the real gross domestic product (RGDP), value of transaction (VOT), foreign private investment (FPINM), All share index (ASI), and the Market capitalization (MCAP) from 1989 to 2006.

Table 1: Statistical Significances using p-value for linear multiple regression analysis.

\begin{tabular}{|lllll|}
\hline Predictors & \multicolumn{1}{c}{ Coeft } & S.E & T-statistic & P-value \\
\hline $\mathrm{b}_{\mathrm{o}}$ & 245742.93 & 10830.78 & 22.634 & 0.000 \\
\hline $\mathrm{b}_{1}$ VOT & 0.644 & 0.586 & 1.100 & 0.291 \\
\hline $\mathrm{b}_{2}$ FPINIM & 0.839 & 0.847 & 0.991 & 0.340 \\
\hline $\mathrm{b}_{3}$ ASI & 10.05 & 2.709 & 3.710 & 0.003 \\
\hline $\mathrm{b}_{4}$ MCAP & -59.34 & 53.266 & -1.114 & 0.285 \\
\hline $\mathrm{R}^{2}=0.968$ & & & \\
\hline Adj $\mathrm{R}=0.959$ & & & \\
\hline F-Ratio=99.716 & & \\
\hline Durbin Watson statistic $=2.203$ & \\
\hline
\end{tabular}

Source: Analysis of Data (2011) Note: Significant at $(\mathrm{P}<0.05)$

Model Equation is expressed by the model analysis as follows;

$\mathrm{RGDP}=245142.9+0.644 * \mathrm{VOT}+0.839 * \mathrm{FPINM}+10.05 * \mathrm{ASI}+-59.34 * \mathrm{MCAP}$

Table 1 shows a multiple regression analysis all the coefficients' were correctly signed. The $b_{0}, b_{1}, b_{2}, b_{3}$, and $b_{4}$ coefficients which represent the real gross domestic product (RGDP), Value of Transactions (VOT), foreign private investment (FPINM), All share index (ASI), and Market capitalization (MCAP) were positively signed. With the p-value 0.000 signifies that the model is statistically significant. The R- square obtained is 0.968 which explained that approximately $97 \%$ of the variability of real gross domestic product is accounted for by the variables in the model. In this study, the adjusted R-square indicates that about $96 \%$ of the variability of real gross domestic products is accounted by the model, even after taking into account the number of predictor variables in the model.

The coefficients for each of the variables indicates the amount of change one could expect in real gross domestic products given a one unite change in the value of that variable, given that all other variables in the model are held constant.

\section{Analysis of Variances Test (ANOVA)}

Since the $p$-value $(0.000)$ when compared to the alpha level $(p<0.05)$ is very small, this shows a statistical significant relationship within the dependent variable (RGDP) and the independent variables reliably predict the real gross domestic products (the dependent variable). This is an overall significant test assessing whether the predictors variables when used together reliably predict the RGDP and those not address the ability of any of the particular predictors variables to predicts the dependent variable (RGDP).

All share index: The coefficient (parameter estimated) is 10.051. Therefore, for every unit increase in all share index, a 10.051 unit increase in real gross domestic product is predicted, holding all other variables constant. This is significantly different from zero $(0)$. 
Foreign private investment: The coefficient is 0.839 . This means that for a one unite increase in foreign private investment; we expect an approximately 0.84 increase in real gross domestic product. This is not statistically significant, in other words 0.84 is not different from zero (0).

Market capitalization: For every unit increase in market capitalization, there is a -59.337 unit decrease in the predicted real gross domestic products, holding all other variables constant. The variable market capitalization is technically not statistically significantly different from zero $(0)$, because the p-value $(0.285)$ is greater than 0.05 $(\mathrm{p}<0.05)$.

Value of Transactions: The coefficient for value of transaction is 0.644 . Hence, for every unit increase in value of transaction we expect a 0.644 increase in the real gross domestic product. Since the p-value 0.291 is greater than 0.05 we conclude that the value of transactions is not significantly different from zero.

\section{Test of Hypothesis}

The hypothesis tested as mentioned in chapter one state that:

$\mathrm{H}_{0}$ : There is no significant impact of capital market on Nigeria's economic development.

$\mathrm{H}_{1}$ : There is a significant impact of capital market on Nigeria's economic development.

In order to test the hypothesis stated the t-value, 2 tailed p-value were used in testing this $\mathrm{H}_{0}$ hypothesis that there is no significant impact of capital market on Nigeria's economic development, that is the coefficient or parameter is zero (0). Since the $\mathrm{p}$-value $(0.000)$ when compared with the alpha level $(\mathrm{p}<0.05)$ is small, which show that the capital market has significant impact on Nigeria's economic development, therefore, $\mathrm{H}_{0}$ is rejected and $\mathrm{H}_{1}$ is thus accepted and conclude that capital market has significant impact on Nigeria's economic development.

\section{Test of Goodness of Fit $\left(\mathbf{R}^{2}\right)$}

The result indicates that $97 \%$ change in real gross domestic product is explained by the explanatory variables include in the model, which only 3\% cannot be accounted for with Durbin Watson statistic of 2.203 indicates the absences of autocorrelation, meaning the model can be used for prediction with high degree of accuracy.

\section{Regression Equation}

RGDP predicted $=245142.9+0.644 * \mathrm{VOT}+0.839 * \mathrm{FPINM}+10.05 * \mathrm{ASI}+-59.34 * \mathrm{MCAP}$

In other to assess the ability of each individual's independent variables to predict the real gross domestic products the parameters of estimates was employed. Table 4.1 shows the predictor variables (constant, ASI, FPINM, MCAP and VOT). The constants (245142.9) i.e. y intercept is weight of the regression line when its crosses the y axis. In other words, this is the predicted value of real gross domestic products when all other variables are zero (0). These estimates indicate the amount of increase in real gross domestic product that will be predicted by a one unit increase in this predictor.

For any predicted variables which are not significant that is signifies that the coefficients are not significantly different from zero (0).

\section{Conclusion}

\section{Conclusions and Recommendations}

This study was aimed at evaluating the impact of capital market on Nigerian economic development from 1989-2006. Some of the major findings realize that; the explanatory variables (constant, ASI, FPINM, VOT and MCAP) have significant impact on economic development of Nigeria. The ability of each individual's independent variables to predict the real gross domestic product was also assessed. Those estimates indicate the amount of increase in real gross domestic product that will be predicted by a one unit increase in the predictor for any predictor variables which are not significant, that is, signifies that the coefficients are not significantly different from zero (0). The all share index was found to be significantly different from zero (0). That is, for every units increase in all share index, a 10.051 unit increase in real gross domestic product is predicted, holding all other variables constant.

The foreign private investment was observed to be not statistically significant in order word, 0.84 obtained is not different from zero (0). The variable market capitalization is technically not statistically significantly different from zero $(0)$, since the $p$-value $(0.285)$ is greater than $0.05(p>0.05)$. The value of transactions indicates that for every unit increase in the value of transactions one can expect a 0.644 increase in the real gross domestic product. Since the $p$-value 0.291 is greater than $0.05(p>0.05)$, we conclude that the value of transaction is not significantly different from zero $(0)$. The analysis conducted indicates that most of the explanatory variables can be use with a high degree of accuracy to predict the dependent variable (RGDP). It also shows that capital market has significant impact on the Nigeria's economic development. Further improvement is necessary in order to enhance economic growth. 


\section{Recommendations}

Based on the findings of this study the following recommendations are made.

1. Improvement in the declining market capitalization by spire more foreign investors to participate in the market.

2. To spire foreign international companies or their supplementary to be listed on the Nigeria Stock Exchange.

3. There is a need to bring back the confidence to the market by regulatory authorities through ensuring clearness and fair trading transactions and dealing in the stock exchange.

4. To increase the value of transactions in the Nigerian capital market, there are needs for accessibility of more investment instruments.

\section{References}

[1]. Afolabi, L. (1999). Monetary Economics, Educational Books (Nig), Ibadan

[2]. Adenikinju, A. (1994), "Trade liberalization, market and productivity in Nigeria, African Economic Research Consortium. Nairobi

[3]. Central Bank of Nigeria(2007). Capital Market Dynamics in Nigeria, Financial Analysis Spector Divisions, Abuja

[4]. Chijoke, A. K. (2002). Contemporary issues in financial management, the professional skills compensation. Knowroch, Ikeja Lagos

[5]. CBN Annual Reports and statement of Accounts 2006, various Issues

[6]. Dada,I.O.(2003). The Nigerian Capital Market. Spectrum Books (Nig), Ibadan

[7]. Jerome, A and Adenikinju, A (1995), Trade policies and the promotion of manufactured Exports in Nigeria. Proceeding of Nigeria Economic Society Annual Conference. (1995), Ibadan

[8]. Koutoyiannis, A. (2003), Theory of Econometrics. Palgrave publishers, London

[9]. Iwegbu, Z. K. (2004). Shareholdings; steps to Financial Empowerment.

[10]. Odife, D. O. (1999). Understanding the Nigerian stock exchange. Heinemann Educational Books (Nig), Ibadan

[11]. Oladeji, R. (2004), The Nigerian stock exchange, fact Book, Walshad, Lagos

[12]. Olorunshola, M. (2002), "Economic Basic Features of NigeriaManufacturing sub-sector in CBN Bullion Vol. 26 No. 4 , 2002

[13]. Onwukiri, O. (2008). The Theory and Practice of capital Market: National board for Technical Education, Kaduna

[14]. Rose, P. S. (1997). Money and capital market financial institution and instrument in a global market place $6^{\text {th }}$ edition. Irwin Book Tea, USA

[15]. Todero, M. P. (2003), “Economic Development", $8^{\text {th }}$ Edition, Pearson Education Asia Www. http://en.wikipedia.org/wiki/Nigeria 